\title{
31. Transduction of Biochemical Properties in Salmonella E Group
}

\author{
By Shoei IseKI and Tatsuo SAKAI \\ Department of Legal Medicine, School of Medicine, Gunma University, Maebashi, Japan \\ (Comm. by T. Furuhata, M.J.A., Feb. 12, 1954)
}

Lederberg et al. ${ }^{1)}$ reported on the production of prototrophs by the action of a filtrable agent (FA) in the lysate of an auxotroph of S. typhi-murium which was elicited by lysogenic phage from auxotroph of the other strain. Zinder and Lederberg's) called this phenomenon "transduction" and it became evident that genetic properties such as nutritional requirement, fermentation of carbohydrates and streptomycin resistant ability can be transferred from one strain to another. It was further elucidated that more than one property can never be transduced in one cell and that fermentative abilities of carbohydrates and $\mathrm{i}$ of phase $\mathrm{I}$ of $\mathrm{H}$ antigen can be transferred to S. typhi by FA of S. typhi-murium. Berry, McCarthy, and Plough ${ }^{3)}$ induced the transduction of various nutritional requirements only by the filtrate of S. typhi-murium. Then Baron, Formal, and Spilman ${ }^{4)}$ reported that when strains which can adsorb Vi phage are treated with lysate of xylose fermentation positive and streptomycin resistant strain of S. typhosa which was produced by the action of Vi phage, then the transduction of these properties is induced. And they added that also in this case two properties can never be transduced in one cell. Previously, $\mathrm{we}^{5}$ elucidated that in Salmonella $\mathrm{E}$ group, III $\mathrm{X}$ antigen of subgroup $\mathrm{E}_{1}$ can be transformed into III XV antigen of subgroup $E_{2}$ by the action of bacteriophage derived from lysogenic strain of subgroup $\mathrm{E}_{2}$. This time we found that transduction of biochemical properties occurred in some bacteria which had their antigens transformed.

\section{Materials and Methods}

1) Strains: By nitrogen mustard treatment of S. anatum of subgroup $\mathrm{E}_{1}$ and $\mathrm{S}$. newington of subgroup $\mathrm{E}_{2}$, the following auxotrophs and mutant of carbohydrate fermentation were obtained for the experiment. S. anatum A-1 : Leucineless $\left(\mathrm{L}^{-}\right)$, maltose $+\left(\mathrm{Mal}^{+}\right)$, streptomycin sensitive $\left(\mathrm{S}^{S}\right)$. S. anatum A-2 : Prolineless $\left(\mathrm{P}^{-}\right)$, maltose $+\left(\mathrm{Mal}^{+}\right)$, streptomycin sensitive $\left(\mathbf{S}^{\mathrm{s}}\right)$. S. anatum A-1': Leucineless $\left(\mathrm{L}^{-}\right)$, maltose $-\left(\mathrm{Mal}^{-}\right)$, streptomycin sensitive $\left(\mathbf{S}^{\mathrm{S}}\right)$. S. newington $\mathrm{N}-1$ : Histidineless $\left(\mathrm{H}^{-}\right)$, maltose $+\left(\mathrm{Mal}^{+}\right)$, streptomycin sensitive $\left(\mathrm{S}^{\mathrm{S}}\right)$.

Streptomycin resistant strains $\left(\mathbf{S}^{r}\right)$ were obtained by selecting 
those which grew well in a medium containing $100 \mathrm{mg}$ per cc of streptomycin (SM).

2) Lysate: $S^{\prime \prime}$ strains with broth were frozen and thawed and then centrifuged to remove the cell debris. The supernatant was filtrated through a Berkefeld filter.

3) Method of investigation: Into the above described lysate mutants were transplanted and cultured at $37^{\circ} \mathrm{C}$ for 48 hours, and then washed by sterile physiological saline solution. To examine for the transduction of nutritional requirement and streptomycin resistance, these were inoculated into minimal medium (MM), ordinary agar medium to which was added $10 \mathrm{mg}$ per cc of SM (SM agar) and minimal medium containing the same rate of SM (MM+ SM). They were cultured at $37^{\circ} \mathrm{C}$ for 48 hours, and the appearance of bacterial colonies was observed. To examine for the transduction of fermentation of carbohydrate, liquid medium was employed with B.T. B. (bromthymolblue) as the indicator. The strains were inoculated into peptone solution containing maltose (Mal+peptone), minimal medium containing maltose $(\mathrm{Mal}+\mathrm{MM})$ and maltose-peptone solution containing $10 \mathrm{mg}$ per cc of SM (SM + Mal + peptone), cultured at $37^{\circ} \mathrm{C}$ for 10 days, and the growth of the bacteria and maltose fermentation were observed. As control, the same experiment was performed with heated lysate.

4) Medium: The composition of the minimal medium is as follows: $\mathrm{NH}_{4} \mathrm{Cl}, 5 \mathrm{~g} ; \mathrm{NH}_{4} \mathrm{NO}_{3}, 1 \mathrm{~g} ; \mathrm{Na}_{2} \mathrm{SO}_{4}, 2 \mathrm{~g} ; \mathrm{K}_{2} \mathrm{HPO}_{4}, 3 \mathrm{~g}$; $\mathrm{KH}_{2} \mathrm{PO}_{4}, 1 \mathrm{~g} ; \mathrm{MgSO}_{4} \cdot 7 \mathrm{H}_{2} \mathrm{O}, 0.1 \mathrm{~g}$; glucose, $5 \mathrm{~g}$; distilled water, $1000 \mathrm{cc}$; purified agar, $15 \mathrm{~g}$.

The composition of the minimal medium for the examination of carbohydrate fermentation is as follows: Sodium succinate, $5 \mathrm{~g}$; $\mathrm{NaCl}, 1 \mathrm{~g}$; $\left(\mathrm{NH}_{4}\right)_{2} \mathrm{SO}_{4}, 5 \mathrm{~g} ; \mathrm{MgSO}_{4} \cdot 7 \mathrm{H}_{2} \mathrm{O}, 1 \mathrm{~g} ; \mathrm{K}_{2} \mathrm{HPO}_{4}, 2 \mathrm{~g}$; maltose, $5 \mathrm{~g}$; distilled water, $1000 \mathrm{cc} ; 0.2 \%$ bromthymolblue, $12 \mathrm{cc}$.

\section{Results}

1. Experiment for transduction: Mutants of S. anatum were inoculated into the lysate of $\mathbf{S}^{\mathrm{r}}$ strain of $\mathrm{S}$. newington, and examined for the transduction of nutritional requirement and SM resistance. The results obtained are shown in Table $\mathrm{I}$.

When heated lysate of $\mathrm{S}^{\mathrm{r}}$ strain was used, no transduction was observed, but when the non-heated lysate was allowed to act upon A-1 $\left(\mathrm{L}^{-}, \mathrm{S}^{\mathrm{s}}\right)$ and A-2 $\left(\mathrm{P}^{-}, \mathrm{S}^{\mathrm{s}}\right)$, many bacterial colonies were formed on MM plate and SM agar plate, which shows that the transduction of nutritional requirement and SM resistance occurred. No colonies were found on SM + MM plate. The bacteria grown on MIN plate did not grow in SM broth, while those grown on SM agar plate 
Table I

The transduction of nutritional requirement and SM resistance by the lysate of S.newington $\mathrm{S}^{\mathrm{r}}$ strain (Number of colonies on the medium)

\begin{tabular}{|c|c|c|c|c|c|c|}
\hline \multirow{2}{*}{\multicolumn{2}{|c|}{$\begin{array}{c}\text { Treatment with } \\
\text { Medium }\end{array}$}} & \multicolumn{2}{|c|}{ Heated $\mathrm{S}^{\mathrm{r}}$ lysate } & \multicolumn{3}{|c|}{ Non-heated $\mathrm{S}^{\mathrm{x}}$ lysate } \\
\hline & & $\mathrm{MM}$ & SM agar & $\mathrm{MM}$ & SM agar & $\mathrm{SM}+\mathrm{MM}$ \\
\hline \multirow{3}{*}{ Strain } & A-1 & 0 & 0 & ca 50 & ca 200 & 0 \\
\hline & A-2 & 0 & 0 & ca 500 & ca 500 & 0 \\
\hline & $\mathrm{N}-1$ & 0 & 0 & 0 & 0 & 0 \\
\hline
\end{tabular}

did not grow in minimal medium. This indicates that either nutritional requirement or SM resistance was singly transduced. All strains produced on these MM plate and SM agar plate were found to have the antigen transformed from III $X$ to III XV. But, when $\mathrm{S}$. anatum was treated with lysate of $\mathrm{S}^{\mathrm{r}}$ strain of $\mathrm{S}$. newington, only in some of the bacteria which had their antigens transformed the transduction of SM resistance and nutritional requirement occurred. When the lysate of $\mathrm{S}^{\mathrm{I}}$ strain of $\mathrm{S}$. newington was allowed to act upon $\mathrm{N}-1\left(\mathrm{H}^{-}, \mathrm{S}^{\mathrm{s}}\right)$ of $\mathrm{S}$. newington no transduction occurred.

When the lysate of $\mathbf{S}^{-}$strain of $\mathrm{S}$. newington was allowed to act upon $\mathrm{A}-1^{\prime}\left(\mathrm{L}^{-}, \mathrm{Mal}^{-}\right)$, the growth of bacteria fermenting maltose was found in $\mathrm{Mal}+$ peptone medium after 48 hours, but in $\mathrm{Mal}+\mathrm{MM}$ and SM+Mal+peptone media such were not found as late as the 10 th day, which indicates that bacteria in which fermentation of carbohydrate was transduced, neither nutritional requirement nor SM resistance was transduced. When lysate of $\mathrm{S}^{\mathrm{r}}$ strain of $\mathrm{S}$. anatum was allowed to act upon $\mathrm{N}-1\left(\mathrm{H}^{-}, \mathrm{S}^{\mathrm{s}}\right)$ of $\mathrm{S}$. newington, the transduction of nutritional requirement or SM resistance was not observed.

2) Action of antiserum : To $\mathrm{S}$. newington $\mathrm{S}^{\mathrm{r}}$ strain lysate was added desoxyribonuclease or anti-phage serum, kept at $37^{\circ} \mathrm{C}$ for 24 hours, and to this was added a mutant of S. anatum to examine for the transduction of nutritional requirement and SM resistance. When desoxyribonuclease was added, the transduction occurred, but in the case of the anti-phage serum it did not.

Next, prototroph, $\mathrm{S}^{\mathrm{r}}$ and maltose fermentation positive strains all obtained by the action of lysate of $S$. newington $S^{\prime}$ strain upon a mutant of $\mathrm{S}$. anatum were each cultured through generations in a broth with the anti-phage serum, and bacteria which, by losing phage had the antigen transformed from III XV to III $\mathrm{X}$ were obtained. In these bacteria, nutritional requirement, SM resistance and maltose fermentation which had been transduced remained unaltered. 


\section{Discussion}

In Salmonella $\mathrm{E}$ group, when strains of subgroup $\mathrm{E}_{1}$ are infected with bacteriophage epsilon $\varepsilon$ from lysogenic strains of subgroup $\mathrm{E}_{2}$, they come to have antigen III XV of $\mathrm{E}_{2}$. In some of these with the transformed antigen, one of the properties of $\mathrm{E}_{2}$, nutritional requirement, SM resistance or fermentation of carbohydrate is singly transduced. The fact that only one of these genetic properties can be transduced by phage perfectly agrees with the observations by Zinder and Lederberg's) with S. typhi-murium and by Baron, Formal, and Spilman ${ }^{4)}$ with S. typhosa. Consequently we know that there are different phages $\varepsilon$ elicited from subgroup $\mathrm{E}_{2}$, some being related only to antigenic transformation, and other, besides this, to the carrying of one factor of genetic properties. And when anti-phage antibody is allowed to react on $\mathrm{E}_{2}$ lysate it loses antigen transforming activity as well as genetic properties transducing activity, which indicates that the transduction does not occur independent of phage. Further, nutritional requirement, SM resistance and fermentation of carbohydrate transduced by phage remain unaltered even when the host loses phage by the action of anti-phage antibody, which indicates that unlike the case of antigenic transformation, the phage is considered to play only the rôle of carrier of filtrable agent in the transduction, as asserted by Zinder and Lederberg. ${ }^{2)}$

\section{Summary}

1. In S. anatum of subgroup $\mathrm{E}_{1}$ of Salmonella $\mathrm{E}$ group occurs antigenic transformation when it is infected with lysogenic phage of $\mathrm{S}$. newington of subgroup $\mathrm{E}_{2}$. At the same time, in some of its cells the transduction of nutritional requirement, streptomycin resistance or maltose fermentation from $\mathrm{E}_{2}$ is observed. In this case, only one factor can be transduced into one cell.

2. The cell into which is transduced one of the genetic properties can maintain this even when it loses its phage by the action of anti-phage antibody and thus has its antigen transformed. Consequently it is considered, as reported by Zinder and Lederberg, that the phage plays only the rôle of carrier of filtrable agent in the transduction.

\section{References}

1) Lederberg, J., Lederberg, E. M., Zinder, N.D., and Lively, E. R.: Recombination analysis of bacterial heredity. Cold Spring Harbor Symp. Quant. Biol., 16, 413-443 (1951). 
2) Zinder, N. D. and Lederberg, J.: Genetic exchange in Salmonella. J. Bact., 64, 679-699 (1952).

3) Berry, M. E., McCarthy, A. M., and Plough, H. H.: Transduction of multiple nutritional requirements in Salmonella typhi-murium. Proc. Nat. Acad. Sci. U.S., 38, 797-803 (1952).

4) Baron, L.S., Formal, S. B., and Spilman, W.: Use of Vi phage lysate in genetic transfer. Proc. Soc. Exp. and Med., 83, 292-295 (1953).

5) Iseki, S. and Sakai, T.: Artificial transformation of $\mathrm{O}$ antigens in Salmonella E group. II. Antigen-transforming factor in bacilli of subgroup $\mathbf{E}_{2}$. Proc. Japan Acad., 29, 127-131 (1953). 